\title{
Numerical Evaluation of Bond Behavior of Ribbed Steel Bars or Seven-wire Strands Embedded in Lightweight Concrete
}

\author{
Mohammed A. Abed ${ }^{1 *}$, Zaher Alkurdi², Ahmad Kheshfeh², Tamás Kovács², Salem Nehme ${ }^{3}$ \\ ${ }^{1}$ Department of Civil and Environmental Engineering, Rutgers University, 08854 New Jersey, Bartholomew Rd. 500, USA \\ ${ }^{2}$ Department of Structural Engineering, Budapest University of Technology and Economics, 1111 Budapest, Múegyetem rkp. 3, \\ Hungary \\ ${ }^{3}$ Department of Construction Materials and Technologies, Budapest University of Technology and Economics, 1111 Budapest, \\ Műegyetem rkp. 3, Hungary \\ * Corresponding author, e-mail: mohammed.abed@rutgers.edu
}

Received: 17 June 2020, Accepted: 14 November 2020, Published online: 30 November 2020

\begin{abstract}
The bond-slip relationship between concrete and steel is significant in evaluating the nonlinear behavior of reinforced concrete structures. The force transmitted by the bond in reinforced concrete structures was studied numerically in high-strength, lightweight concrete with ribbed reinforcing steel bar or seven-wire strand, using ATENA 3D software. The first part of the study was a validation of the model based on the actual results of standardized pull-out tests using the software. Subsequently, the bond behavior was studied, where a four-point static bending test was modeled based on the real bond-slip relationship of the pull-out test. It was deduced that the ATENA 3D software can simulate the experimental tests and provide meaningful results. In addition, inferred from the numerical modeling, the maximum crack width and the mid-span deflection of the reinforced concrete beam increased when the bond stress between the concrete and the reinforcing steel bars was decreased. When a high amount of reinforcement (two strands) was used, concrete failure occurred before the strands yielded. However, further increase of the bond stress also decreased the maximum crack width and mid-span deflection. The failure occurred due to the increase in the strand yielding point by using one strand as a reinforcement of the beam.
\end{abstract}

\section{Keywords}

numerical analysis, pull-out test, four-point static bending test, steel-concrete bond, seven-wire strand, ribbed steel bar, lightweight concrete

\section{Introduction}

Reinforced concrete is one of the most commonly used structural materials in civil engineering. Most facilities today are made from concrete or have concrete as one of the main materials used in structures [1]. Reinforcement is embedded in the concrete to supply equilibrium and control of deformation after cracking. Many studies have been conducted to examine the effect of reinforcement bar properties on the structural behavior of reinforced concrete members. To ensure the joint between reinforcement and concrete functions, however, many researchers have studied the behavior of the bond between different types of concrete and reinforcement [2]. Much of the research concluded that the bond between reinforcement and concrete can be defined as uniform shear stress over the surface of the bar, a simple and entirely inaccurate concept $[3,4]$.
The movement of concrete and steel materials at the interface is different, which leads to a relative displacement of the reinforcement bar in relation to the surrounding concrete. This movement, called slip-bond stress, was created to resist interstitial slide leading to the transfer of tensile stress to the concrete, ending with local high strains in a concrete layer near the reinforcement (interface) [5]. Generally, the bond stress-slip relationship is used to describe the bond behavior between reinforcing steel and concrete, as shown in Fig. 1 [6].

Many parameters directly or indirectly affect the strength of the bond between reinforcement and concrete, which refers basically to the reinforcing unit (bar, multiwire strand, tendon), concrete, and the stress state in both the reinforcing unit and the surrounding concrete. Like 


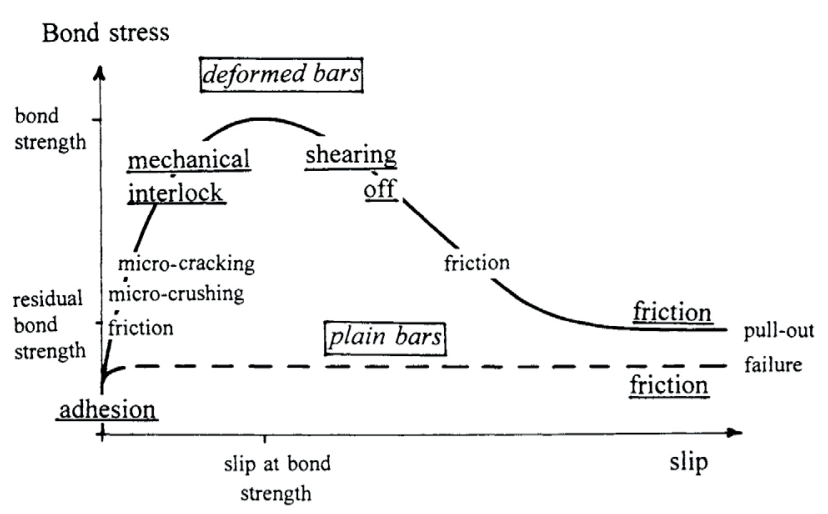

Fig. 1 Phases of steel-concrete interaction for plain and ribbed bars [6]

the length and diameter of the embedded bar, the concrete type also affects the bond behavior in reinforced concrete; the bond strength differs between normal-weight concrete and lightweight concrete (LWC) [7]. In addition, the concrete varies with the materials used for preparing the paste of concrete, such as self-compacting concrete and highstrength concrete $[8,9]$. ACI 213-87 defines the structural LWC as concrete that a) has a minimum compressive cylindrical strength at 28 days of $17.24 \mathrm{MPa}, \mathrm{b}$ ) has a corresponding air-dry unit weight not exceeding $1850 \mathrm{~kg} /$ $\mathrm{m}^{3}$, and c) consists of all lightweight aggregate (LWA) or a combination of LWA and normal-weight aggregate [10]. The major advantage of using LWC in construction is reducing the structural dead load of concrete elements and cross-section of load-bearing elements; therefore, savings in transportation costs can be realized. In contrast, LWC is very sensitive to water content in the mixtures [11].

Chen et al. [12] carried out pull-out tests to measure the bond strength between the reinforcing steel bar and the concrete, and they used two types of concrete, normal-weight concrete and LWC with three groups of compressive strength levels of 20,40, and $60 \mathrm{MPa}$. The results showed that the bond strength of LWC is lower than that of normal-weight concrete when the compressive strength is less than $40 \mathrm{MPa}$. However, it is almost similar to the normal-weight concrete when the strength is higher than $40 \mathrm{MPa}$. LWC possesses higher mortar strength than normal-weight concrete, thus the bond strengths of LWC increases. In addition, their results showed that the use of stirrups leads to an increase in the nominal bond strength by up to $20 \%$ for LWC and normal-weight concrete at any strength level. Also, in most of the research, it was found that the increase of the reinforcing steel diameter contributed to the decrease in the bond strength in LWC [13-17].

Pul [18] compared the bond strength of the normal-weight concrete and LWC with plain and ribbed steel bars. The results of the pull-out test showed that the bond strength is $35 \%$ greater in the plain bar embedded in LWC than in normal-weight concrete. This was attributed to the presence of micro-grains in the tuff aggregate, which improved the adhesion between the reinforcement and concrete. The researcher also pointed out that the bond strength of the ribbed steel bar embedded in LWC is greater compared with other types of steel bars.

Gulyás et al. [19] carried out the pull-out test to describe the bond behavior between seven-wire prestressing strands and LWC. The bond stress-relative slip curve obtained from the test has been compared with the seven-wire strands, according to fib Bulletin 51 [20] on the one hand, as well as with ribbed bars according to fib MC1990 and 2010 [21, 22] on the other hand. As shown in Fig. 2, the bond-stress relative slip curve obtained from the test is fit to those of fib Bulletin 51.

Yoo and Shin [23] investigated the bond behavior of ribbed steel rebar embedded in high-strength concrete, veryhigh-strength concrete, and ultra-high-strength concrete. The compressive strength of the different types of concrete mixtures after 28 days were 80,120 , and $180 \mathrm{MPa}$,

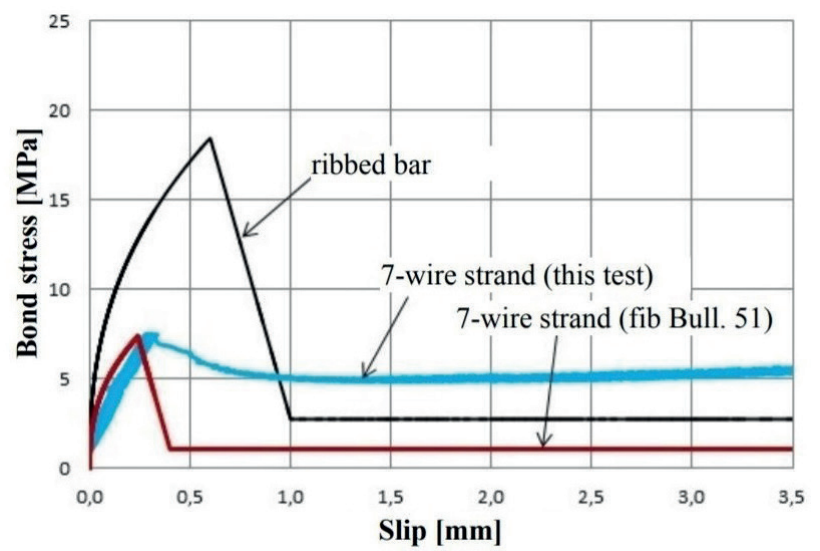

(a)

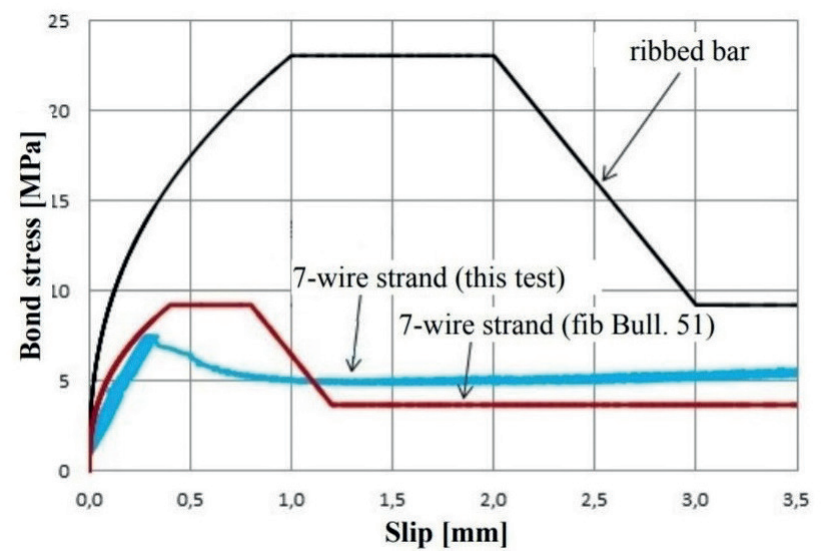

(b)

Fig. 2 Bond stress-slip curves for ribbed bars and seven-wire strand according to fib Bulletin 51: a) MC1990 and b) MC2010 [19] 
respectively. Test results indicated that with increase in the compressive strength of the concrete, the bond strength between reinforcing steel bars and the concrete increased significantly. Fig. 3 shows the bond stress-relative slip relationship in concrete with different compressive strengths. Furthermore, they concluded through their study that the bond strength of self-compacted concrete is higher than of the vibrated concrete because of greater filling capacity and reduced bleeding as alluded to earlier.

To fully capitalize on the benefits of prestressed concrete, the prestressing force must be sufficiently transferred to the concrete member, and the member must be able to benefit from the tensile strength of the reinforcement to reach its entire moment capacity [24]. The bond resistance between the strand and surrounding concrete is developed due to the following: the adhesion between the strand and concrete, the mechanical interaction due to the shape of the strand, and the Hoyer effect as shown in Fig. 4 [26]. $\mathrm{Li}$ and Yuan [25] published a report on four stages that explained the bond action between a strand steel bar and the surrounding concrete: the elastic stage, the strengthening stage, the softening stage, and the residual stage.

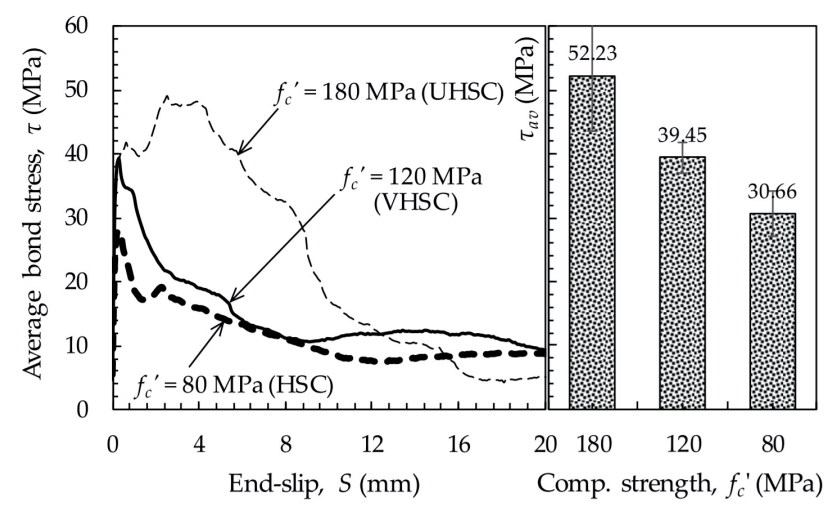

Fig. 3 Effect of compressive strength grade on the bond performance of steel bar in concrete with different strengths [23]

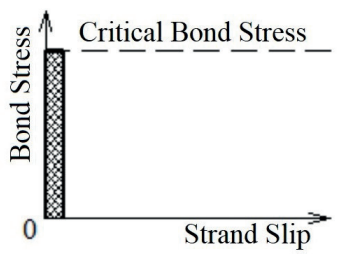

(a) Adhesion

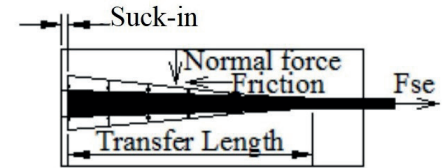

(b) Hoyer's effect

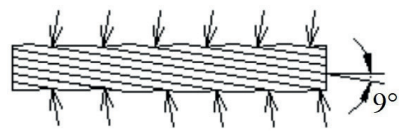

(c) Mechanical interlock

Fig. 4 Bond mechanics of seven-wire strand [26]
A large number of studies, most of them laboratory experiments, have been conducted to study the bond. Chao et al. [27] compared the bond behavior between a ribbed reinforcing bar and seven-wire strand with the same nominal diameter. The reinforcing steels used in their research were embedded in fiber-reinforced cementitious composites and conventional concrete (with no fiber). The former potentially enhanced the bond because of the material's superior tensile behavior and ductility, compared with conventional concrete. Fig. 5 shows that the bond stress for the ribbed steel bar is higher than for the seven-wire strand. Besides, the bond stress is much higher in seven-wire strand embedded in fiber-reinforced cementitious composites matrices than in conventional concrete matrices. As for the bond mechanism, in the ribbed steel bar, the bond strength is produced due to the bearing force originating from the projecting ribs of the bar. But in seven-wire strand, an unrestrained strand tends to move helically along the path formed rather than pulling out directly from the fiber-reinforced concrete matrix by the surrounding tunnel of concrete like a screw coming out from its screw hole. Because of the formation of narrow cracks, the strand and fiber-reinforced concrete matrix keep tight during pull-out, offering significant friction and mechanical interlocking as shown in Fig. 6.

For a deeper understanding of the bonding mechanism, the effect of the different factors on the bond, and for the full explanation of the failure mode, many researchers have used finite element software such as ABAQUS and ATENA. Yu and Jeong [28] developed a model for studying the bond between different types of wire and concrete using ABAQUS software and indicated that the simulation results agree reasonably well with the test data. Tavares et al. [29] studied bond behavior for different bar diameters

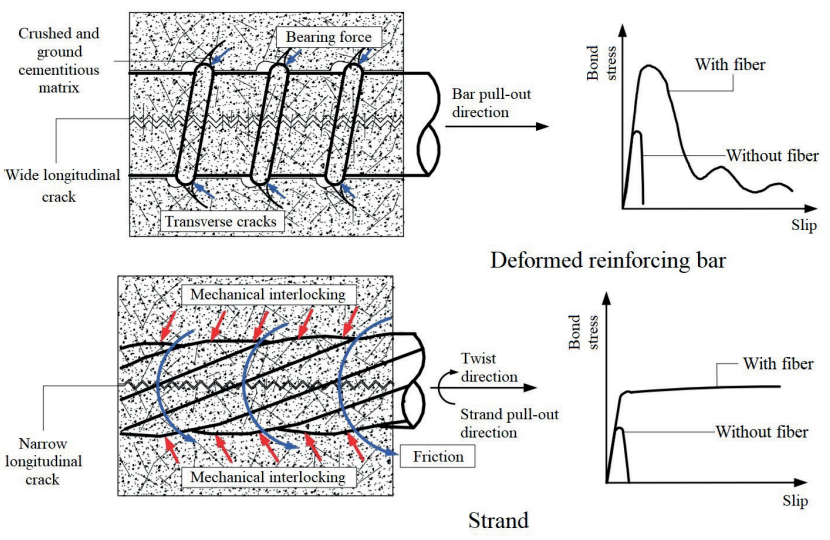

Fig. 5 Comparison of bond behavior between ribbed reinforcing bar and strand with same nominal diameter [27] 

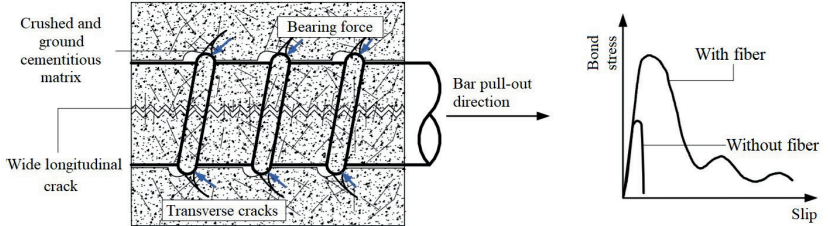

Deformed reinforcing bar

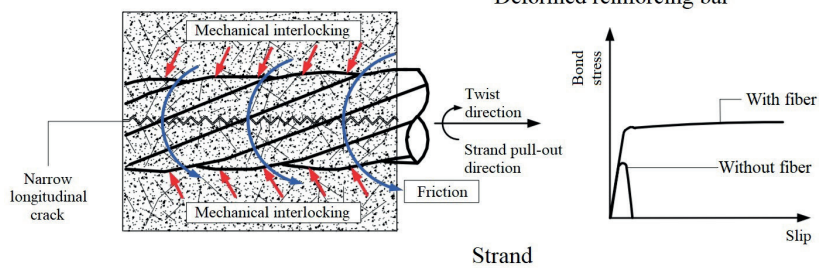

Fig. 6 Bond mechanisms between fiber-reinforced cementitious composites and ribbed reinforcing bars or strands [27]

using ATENA software. They showed numerical results in the range of experimental results with small differences. Therefore, more research is needed to understand bond behavior between reinforcing steel and LWC numerically.

\section{Methodology}

This study comprises numerical modeling efforts aimed at enhancing the understanding of the bond behavior between high-strength LWC and reinforcing steel bar on the one hand, and seven-wire strand on the other. The bond test used in this study was the pull-out test and the flexural test of the reinforced concrete beam, which was the four-point static bending test. ATENA 3D software was used in this research to simulate the real behavior of concrete structures, including reinforcement yielding, concrete cracking, and crushing [30]. Furthermore, ATENA is specially designed for concrete, which makes it easier to use because good default values are given.

The LWC mix produced by cement, water, fine aggregate fraction $(0 / 4 \mathrm{~mm})$ quartz, and Liapor $(4 / 8 \mathrm{~mm})$ as a coarse aggregate. Liapor $8 \mathrm{~F}$ is an expanded clay type with pebble fraction which used to produce a LWC with high strength and $1912 \mathrm{~kg} / \mathrm{m}^{3}$ body density and $85.3 \mathrm{MPa}$ average compressive strength, thus relatively low $w / c$ ratio has been used $(w / c=0.35)$; Table 1 shows the LWC mix proportion.

Ribbed reinforcing steel bar and seven-wire strand with $10 \mathrm{~mm}$ and $12.5 \mathrm{~mm}$ diameter and $673 \mathrm{MPa}$ and $1780 \mathrm{MPa}$ tensile strength, respectively, were used as the reinforcing steel. Table 2 and Table 3 show the chemical composition and mechanical properties of the ribbed steel bar and sevenwire strand.

\subsection{Pull-out test}

To investigate the bond performance of reinforcing steel embedded in LWC, the pull-out test was conducted according to the RILEM recommendation for steel reinforcement $[31,32]$. A cubic sample of $15 \mathrm{~cm}$ of LWC was poured with the reinforcement inside the cube, with an embedment length of five times the diameter of the ribbed steel bar or the seven-wire strand. During the test, the relative displacements between the bar and the concrete cube was measured at both the loaded end $(\mathrm{La})$ and the unloaded end $(L f)$ of the specimen by one pair of inductive transducers on both ends fixed to the steel bar (see Fig. 7). Loaded end displacement $(L a)$ was then further adjusted to allow for the elongation of the steel bar along the length, $L a$. The bond-slip relationship was determined by the iterative process given in [31] considering both the loaded end and the unloaded end relative displacements. In this research, displacement-controlled loading was applied

Table 1 Mix proportion of LWC

\begin{tabular}{|c|c|c|c|c|c|}
\hline \multicolumn{6}{|c|}{ Proportions in $\mathrm{kg} / \mathrm{m}^{3}$} \\
\hline 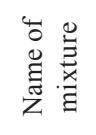 & 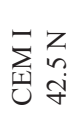 & $\begin{array}{c}\text { Fine aggregate } \\
\text { Natural Sand } \\
0 / 4\end{array}$ & $\begin{array}{c}\text { Coarse aggregate } \\
\text { Liapor } 8 \mathrm{~F} \\
4 / 8\end{array}$ & $\begin{array}{l}\Xi \\
\stackrel{\Xi}{\Xi} \\
\frac{0}{0}\end{array}$ & 离 \\
\hline $\begin{array}{l}\text { Mix of } \\
\text { LWC }\end{array}$ & 460 & 622 & 621 & 1.15 & 160 \\
\hline
\end{tabular}

Table 2 Chemical composition on heat and mechanical properties of the ribbed steel bar

\begin{tabular}{|c|c|c|c|c|c|c|c|c|c|c|c|c|c|}
\hline $\mathrm{C}$ & $\mathrm{P}$ & $\mathrm{S}$ & $\mathrm{Cu}$ & $\mathrm{N}$ & $\mathrm{Ceq}$ & Diameter & $\begin{array}{l}\text { Actual } \\
\text { diameter }\end{array}$ & $\begin{array}{l}\text { Weight } \\
\text { toll. }\end{array}$ & $\begin{array}{l}\text { Yield } \\
\text { stress }\end{array}$ & $\begin{array}{l}\text { Tensile } \\
\text { strength }\end{array}$ & $\begin{array}{l}\text { Tensile to yield } \\
\text { strengths ratio }\end{array}$ & $\begin{array}{l}\text { Elongation } \\
\text { (A10) }\end{array}$ & $\begin{array}{c}\text { Elongation } \\
\text { (Agt) }\end{array}$ \\
\hline$\%$ & $\%$ & $\%$ & $\%$ & $\%$ & $\%$ & $\mathrm{~mm}$ & $\mathrm{~mm}$ & $\%$ & $\mathrm{MPa}$ & $\mathrm{MPa}$ & $\%$ & $\%$ & $\%$ \\
\hline 0.16 & 0.024 & 0.026 & 0.49 & 0.01 & 0.34 & 10 & 9.88 & -2.4 & 570 & 673 & 1.18 & 18.1 & 11.9 \\
\hline
\end{tabular}

Table 3 Mechanical properties of the seven-wire strand

\begin{tabular}{|c|c|c|c|c|c|c|c|c|c|c|c|c|c|c|}
\hline Diameter & $\begin{array}{l}\text { Cross- } \\
\text { sectional } \\
\text { area }\end{array}$ & $\begin{array}{l}\text { Breaking } \\
\text { load (Fm) }\end{array}$ & $\mathrm{Rm}$ & $\begin{array}{c}0.01 \% \\
\text { Proof load } \\
(\text { Fp } 0.01)\end{array}$ & Rp 0.01 & $\operatorname{Rp} 0.1$ & Fp 0.2 & Rp 0.2 & Ft1 \% & Rt $1 \%$ & Em & At & Agt & $\begin{array}{c}\text { Fp0 to } \\
\text { Fm ratio }\end{array}$ \\
\hline $\mathrm{mm}$ & $\mathrm{mm}^{2}$ & $\mathrm{kN}$ & $\mathrm{MPa}$ & $\mathrm{kN}$ & $\mathrm{MPa}$ & $\mathrm{MPa}$ & $\mathrm{kN}$ & $\mathrm{MPa}$ & $\mathrm{kN}$ & $\mathrm{MPa}$ & $\mathrm{GPa}$ & $\%$ & $\%$ & \\
\hline 12.5 & 93 & 180.81 & 1948 & 146.88 & 1582 & 1780 & 168.73 & 1818 & 165.99 & 1788 & 196.05 & 5.74 & 5.64 & 0.91 \\
\hline
\end{tabular}


by a Zwick/Roell Z400-type device, with constant 0.05 and $0.005 \mathrm{~mm} / \mathrm{sec}$ loading rate for ribbed steel bar and seven-wire strand, respectively. The tensile force was increased up to the failure of the bond or the splitting of the concrete cube. Fig. 7 and Table 4 illustrate the dimensions of the specimens and the test arrangement, which, $c$ is the height of the cubic specimen, $L f$ and $L a$ are the initial lengths of the inductive transducers at the loaded and the unloaded end, respectively.

After discussing and analyzing the results from the experimental side in the previous section, an inverse analysis was executed by ATENA 3D, where the compressive strength of LWC was entered into the program. Regarding the reinforcing bars, the properties and bond stress-relative slip curves were defined according to the experiments of the pull-out test. The tension force of the reinforcement bar cannot be applied directly on the reinforcement in the software. Hence, a small modification was made by defining a small elastic cube at the top of the reinforcing steel in the place of the force application. Young's modulus of the elastic cube was greater than for the reinforcing steel. The deformation of the elastic cube was negligible due to its small value compared to the other deformations [33].
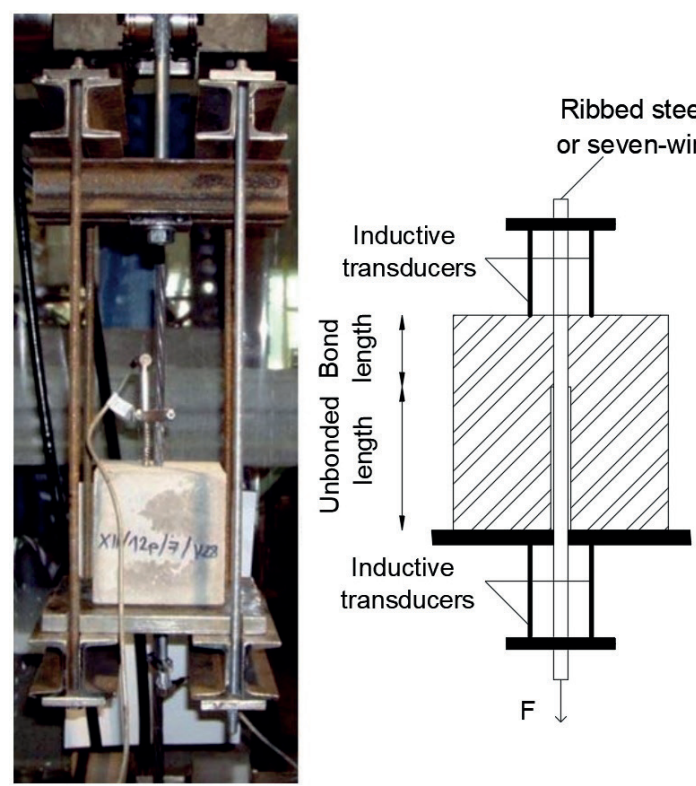

Fig. 7 The dimensions and the test arrangement [19]

\begin{tabular}{ccccc}
\multicolumn{5}{c}{ Table 4 The dimensions and the test arrangement } \\
\hline $\begin{array}{c}\text { Specimen } \\
\text { number }(\#)\end{array}$ & $\begin{array}{c}\text { Age } \\
\text { (day) }\end{array}$ & $L f(\mathrm{~mm})$ & Dimensions \\
\hline 1 & 52.5 & 61.5 & 150.0 \\
2 & 28 & 51.5 & 59.1 & 151.4 \\
3 & & 57.0 & 61.5 & 151.1 \\
\hline
\end{tabular}

A displacement load was used in the pull-out test, where the load was applied at the bottom surface of the top cube, as shown in Fig. 8. The loading history for the analysis was defined, which consists of load steps, and each load step was defined as a combination of load cases. For the solution method, Newton-Raphson was used in the software. The objective of defining the loading history was to keep increasing the load up to failure. During nonlinear analysis, it is useful to monitor forces, displacements, or stresses in the model. The monitored data can provide important information about the state of the model and to obtain the required bond stress-relative slip curve. Therefore, three monitoring points were defined in the numerical modeling. The first point monitored the force applied at the reinforcing steel bar. The other two monitoring points were located along the reinforcing steel bar. The second point monitored the stress of the reinforcing steel bar and the last point monitored the displacement at the unloaded end.

\subsection{Four-point static bending test}

In this section, the numerical modeling of the reinforced concrete beam was developed. The reinforced concrete beam was placed on two supporting pins a set distance apart and two loading pins placed at an equal distance around the center, as shown in Fig. 9. These two loadings are lowered from above at a constant rate until sample failure. The span of the reinforced beam used in this study is $3.8 \mathrm{~m}$. The geometry, cross-section of the reinforced beam, and the position of the loading spins are shown in Fig. 10 and Fig. 11. The reinforcement steels are placed at the bottom of the reinforced beam, where the tensional area. The

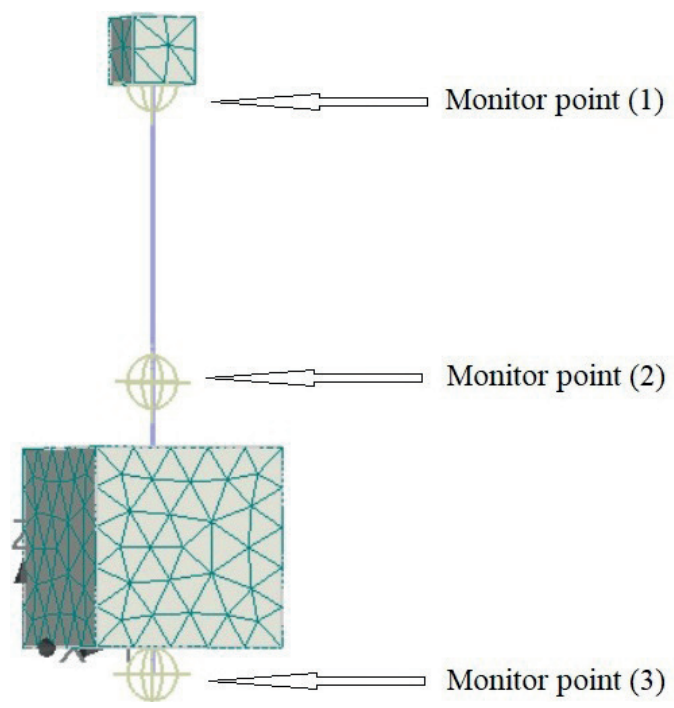

Fig. 8 The program display of the pull-out model and the location of the monitor points 


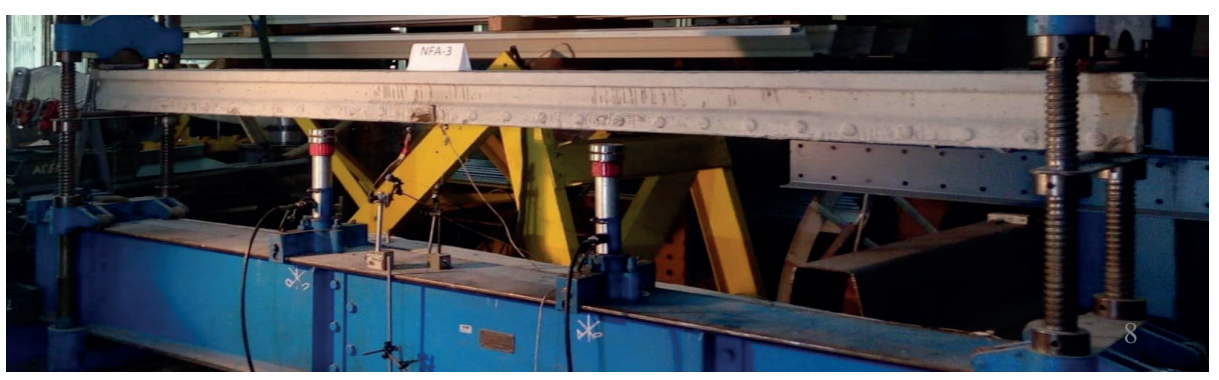

Fig. 9 The four-point static bending test

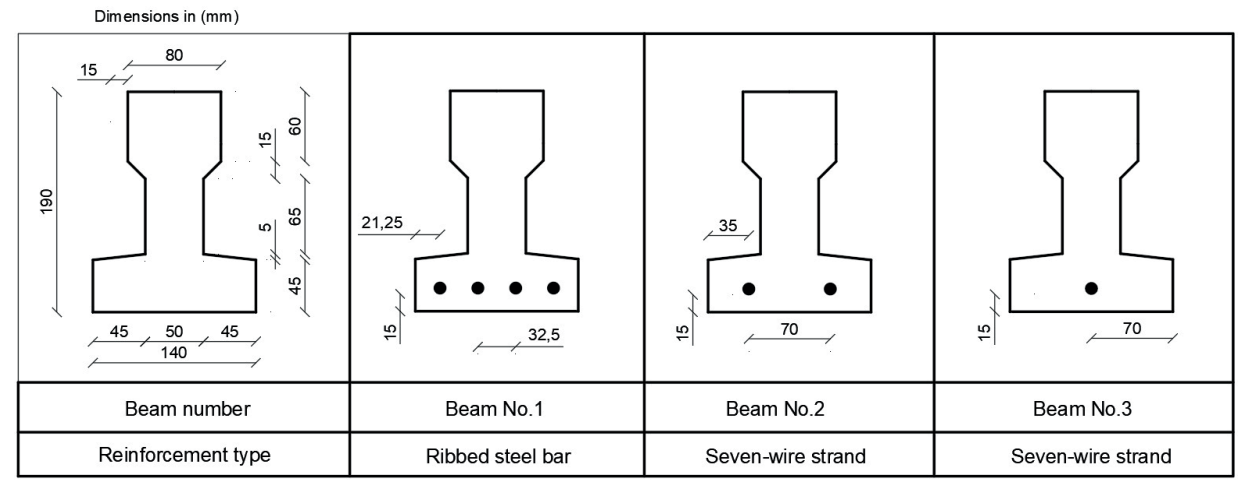

Fig. 10 Cross-section of the reinforced beams

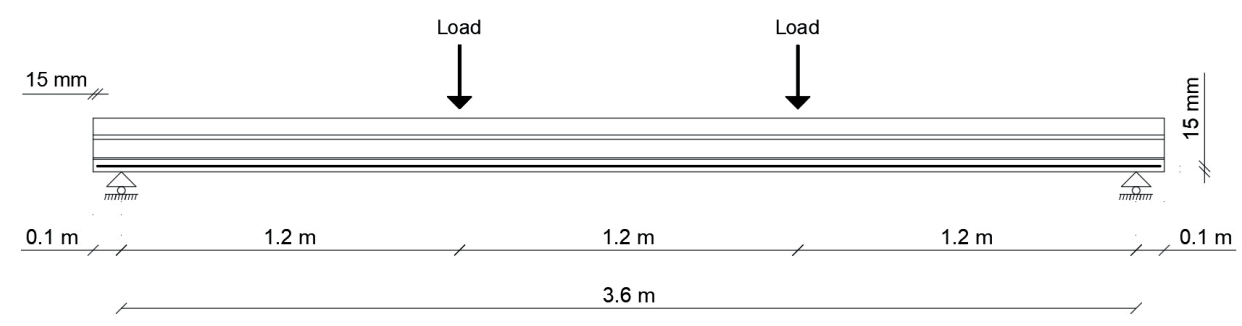

Fig. 11 The geometry of the reinforced beam

diameters and the properties of the ribbed steel bars and seven-wire strand, as well as the properties of the concrete used in this test are the same as was used in the pull-out experiments.

In ATENA 3D, besides defining the materials and the parameters for the concrete and reinforcing steels, steel plates with $3 \mathrm{~cm}$ thickness were placed at the top of the beam. The displacement loads were applied at the steel plates instead of applying the loads directly on the reinforced beam, to avoid early cracking resulting from the loading, as recommended by the software manual [33]. In addition, the steel plates were also used for the supports of the reinforced beam, as shown in Fig. 12. Two monitoring points were defined in the numerical modeling. The first monitor point was defined for monitoring the force applied at the top steel plate. The second monitor point was located at the middle of the beam near its bottom surface, where the largest vertical displacements can be expected. Thus, the required load-deflection curve can be obtained.

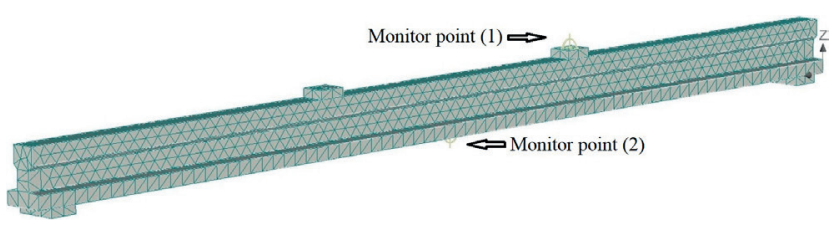

Fig. 12 The program display of the four-point bending model and the location of the monitor points

For the ribbed bars as a reinforcement (beam No. 1), four bond stress-relative slip curves were used in this study. The first curve is the full bond which was obtained from the laboratory experiment (pull-out test), and for the remaining curves, the bond stress was divided by $1.1,1.2$, and 1.3 to note the behavior of the reinforced concrete beam before and at the failure of the beam. For that, the bond stress was reduced to $9.1 \%, 16.7 \%$, and $23.1 \%$.

As to the seven-wire strands, two cases were investigated; the first case was to investigate two beams with two seven-wire strands as a reinforcement (beam No. 2), while the second case was to investigate two beams with 
one strand as a reinforcement (beam No. 3). Regarding the bond stress-slip curve that was used in the two beams, the same slip values from the pull-out model were used (whole bond). However, the bond stress values were multiplied by a factor equal to 2 and 1.2 for beam No. 2 and beam No. 3 , respectively. The displacement at the middle of the beam near its bottom surface at the failure and the maximum crack width were determined for both. The results were compared and the effect of the bond stress between the reinforcing steel and concrete was noted.

\section{Numerical modeling results of the pull-out test}

\subsection{Ribbed steel bar}

The double curve chart shown in Fig. 13 depicts the relationship between the bond stress and relative slip of the ribbed steel bar where the two curves are the results obtained from the laboratory experiment and the numerical modeling. Generally, the stress increased dramatically concurrently with pulling the steel bar, and after reaching about $18 \mathrm{MPa}$ the stress increased gradually until the peak was reached and suddenly the curve plummeted. To clarify, when the test started, the steel bar started pulling difficulty as a result of the friction between the concrete and around the surface of the ribbed steel bar. The stress increased in combination with slipping, then the steel bar was visibly still slipping, and finally, the steel bar was pulled out of the cube. The test culminated in breaking of the bond between the steel bar and concrete. It could, therefore, be concluded that the failure type of the test is a pull-out failure. The maximum bond stresses obtained from the experiment and the software were 21.19 $\mathrm{MPa}$ and 20.85 $\mathrm{MPa}$, and the corresponding relative slips were $0.46 \mathrm{~mm}$ and $0.40 \mathrm{~mm}$, respectively.

\subsection{Seven-wire strand}

In the seven-wire strand, the situation was the same, and it was found that the software gave almost the same values as the laboratory test values, as shown in Fig. 14. In the increasing part, the two curves have the same inclination and the corresponding maximum force in both the experiment and the software, where the maximum force in the experiment was $19.07 \mathrm{kN}$ (bond stress $=7.77 \mathrm{MPa}$ ), and the maximum force in the software was $19.08 \mathrm{kN}$ (bond stress $=7.77 \mathrm{MPa}$ ). The same slip value corresponding to the maximum bond stress was obtained, which was $0.026 \mathrm{~mm}$. In the decreasing section, it was found that the slope is slightly different in both the software and the experiment, but this difference was very small and could be neglected; the same results were found in the

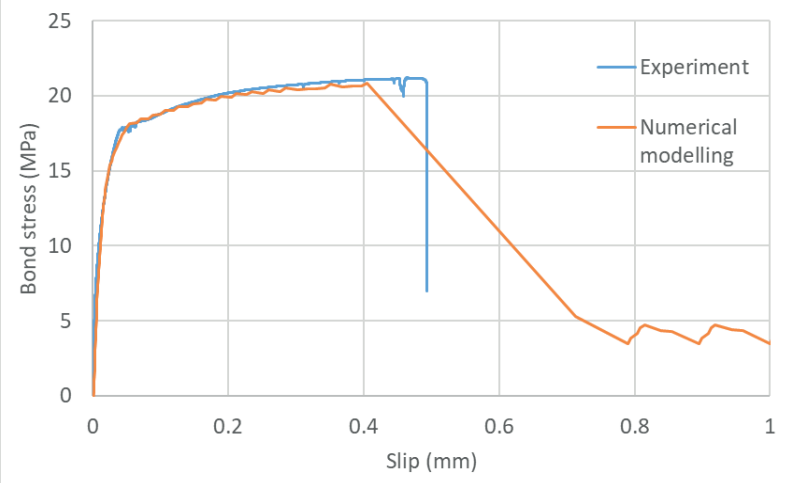

Fig. 13 Comparing the bond stress-relative slip curves between the experiment and numerical modeling (ribbed bar)

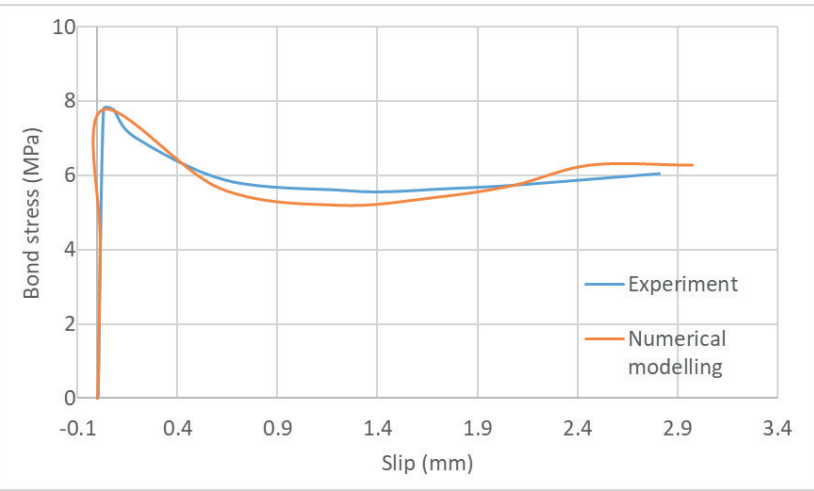

Fig. 14 Comparing the bond stress-relative slip curves between the experiment and numerical modeling (seven-wire strand)

previous studies by Tavares et al. [29] and Bolmsvik and Lundgren [34]. Based on the results, the ATENA 3D software gave a perfect simulation of the pull-out test, and the same results as the laboratory results were obtained.

\subsection{Comparing the bond behavior for each ribbed steel} bar and seven-wire strand with lightweight concrete

Previous results showed that the failure type of the steelconcrete interaction is a pull-out failure. For more clarity regarding the failure type, Fig. 15 and Fig. 16 show the crack pattern of the concrete specimen using ribbed steel bar after pull-out failure, and the development of the crack during the pull-out process using seven-wire strand. The figures show just the visible cracks in the reality where the hidden cracks have been filtered.

As noted in the figures above, for ribbed steel bar and seven-wire strand alike, the cracks occurred inside the specimen and specifically around the bond area where the bond between the reinforcing steel and the concrete hindered the pull-out process, as well as no obvious cracks at the surface of the concrete cube. This confirms that the failure type is a pull-out failure, and the concrete used is highstrength concrete with compressive strength of $85.3 \mathrm{MPa}$. 


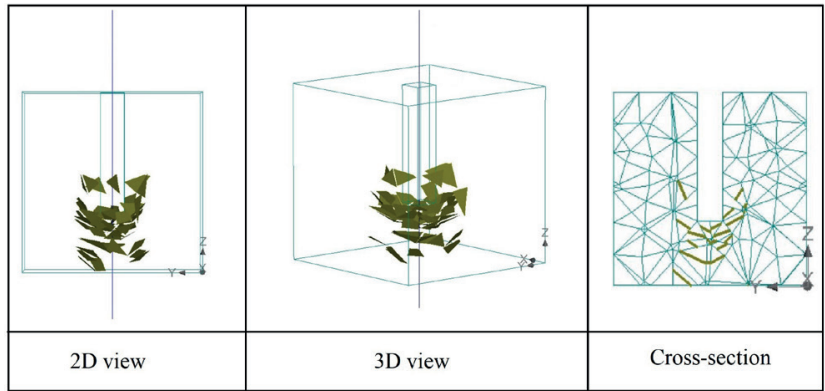

Fig. 15 Crack pattern of the concrete cube (LWC) after pull-out failure

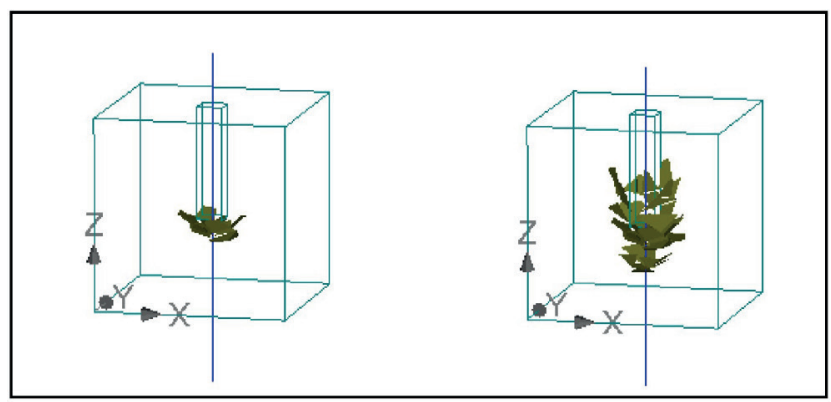

Fig. 16 Crack development of seven-wire strand embedded in LWC

Fig. 17 compares the bond stress-relative slip curves for the ribbed steel bar and seven-wire strand, where the bond stress in case of the ribbed steel bar incorporated in LWC is about $60 \%$ higher than for the seven-wire strand. This difference in bond stress values for the steel bar and seven-wire strand corresponds to the results found in previous studies by Gulyás et al. [19] and Chao et al. [27]. On this basis, it may be concluded that the numerical results have an equivalent behavior to the results of the experimental test for either ribbed steel bar and seven-wire strand.

Moreover, ATENA software can predict and explain each of the behaviors of steel reinforcement and steel anchors in concrete structures in a consistent way. It can be effectively used to support and extend experimental investigations for innovative solutions in the field of connections between steel and concrete. Regarding the maximum value of the bond stress and the corresponding slip value, the values were compared between the laboratory experiment and the numerical modeling, presented in Table 5.

\section{Numerical modeling results of the four-point bending test 4.1 Ribbed steel bar}

Concerning the ribbed steel bars as a reinforcement (beam No. 1), the first case where the whole bond stress was used, the relationship between the load and the deflection at the mid-span is shown in Fig. 18, where the loads were recorded for one side. As illustrated in Fig. 18, after the yielding of the reinforcing steel bars, the beam reached

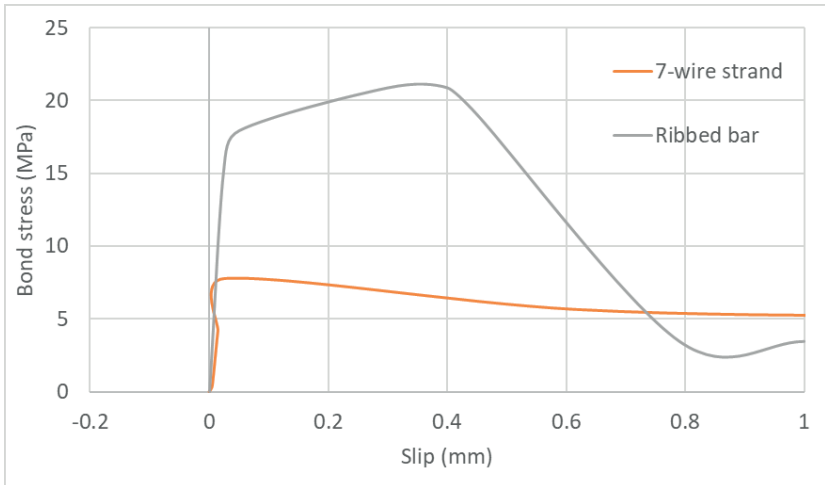

Fig. 17 Comparing the bond stress-relative slip curves between the ribbed bar and seven-wire strand with LWC

Table 5 Comparing the maximum bond stress and the relative slip curves between the laboratory experiment and the numerical modeling

\begin{tabular}{lcccc}
\hline & \multicolumn{2}{c}{ Ribbed steel bar } & \multicolumn{2}{c}{ Seven-wire strand } \\
& $\begin{array}{c}\text { Maximum } \\
\text { bond stress } \\
(\mathrm{MPa})\end{array}$ & $\begin{array}{c}\text { Relative } \\
\text { slip }(\mathrm{mm})\end{array}$ & $\begin{array}{c}\text { Maximum } \\
\text { bond stress } \\
(\mathrm{MPa})\end{array}$ & $\begin{array}{c}\text { Relative } \\
\text { slip (mm) }\end{array}$ \\
\hline $\begin{array}{l}\text { Laboratory } \\
\text { experiment }\end{array}$ & 21.19 & 0.46 & 7.77 & 0.026 \\
$\begin{array}{l}\text { Numerical } \\
\text { modelling }\end{array}$ & 20.85 & 0.40 & 7.77 & 0.026 \\
\hline
\end{tabular}

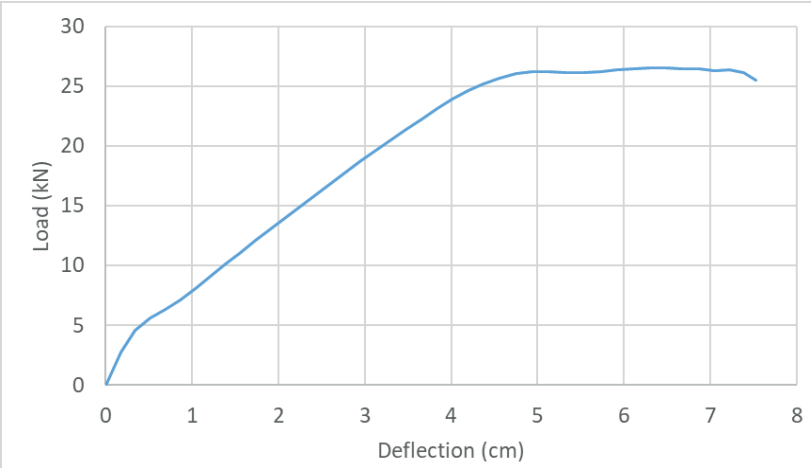

Fig. 18 The load-deflection curve for beam No. 1

failure. The ultimate load is equal to $26.54 \mathrm{kN}$, and the corresponding mid-span deflection is equal to $7.39 \mathrm{~cm}$. The failure type is a flexural failure where the reinforced concrete beam reached failure by crushing of the concrete long after the yielding of the steel bars. It is also noted from the curve that the cracks start to appear in the midspan region of the beam at about $5 \mathrm{kN}$.

The linear-elastic behavior followed by the appearance of several cracks in the mid-span region of the beam, at the nonlinear phase, numerous flexural cracks and considerable deflections have been recorded. As the load increased, the stiffness of the beam changed dramatically with the yielding of the internal steel reinforcements, as shown in 
the graph (Fig. 18). The influence of the bond stress was studied at the failure of the reinforced beam. The relationship between the deflection and maximum crack width of every bond stress value was determined. In all cases, the maximum loads were the same to a certain extent where yielding of the steel bars in tension occurred. When the bond stresses were 20.85, 18.95, 17.37, and 16.04 MPa, the maximum mid-span deflection values at the failure of the reinforced concrete beam were 7.39, 7.99, 8.08, and $8.44 \mathrm{~mm}$, respectively, as shown in Fig. 19. It could be seen that decreasing the maximum bond stress increased the maximum deflection. The same results were found in the previous study by Mousa [35]. A linear regression could present this relationship perfectly with a relatively high coefficient of determination $R^{2}=0.9416$ and for the same concrete type.

Also, a linear regression presented the relationship between the maximum bond stress and maximum crack width with a coefficient of determination $R^{2}=0.9405$, whereby increasing the maximum bond stress decreased the maximum crack width when the same type and strength of concrete were used. Fig. 20 shows the maximum crack

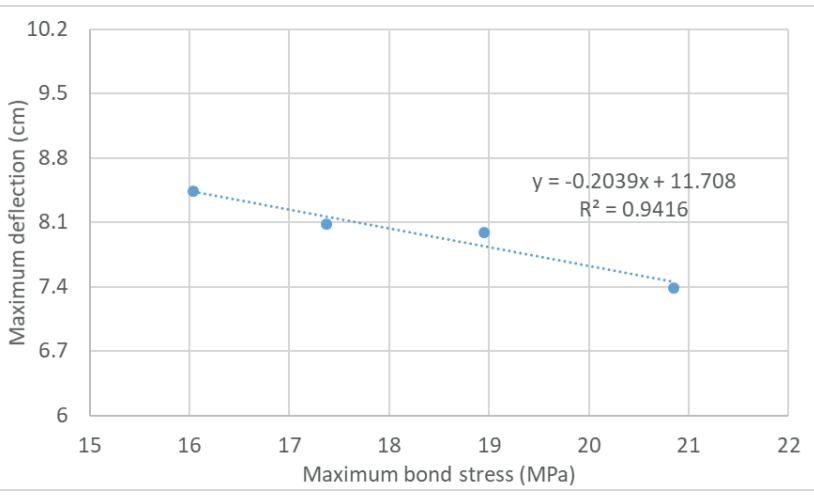

Fig. 19 The relationship between the maximum bond stress and the corresponding deflection at the failure

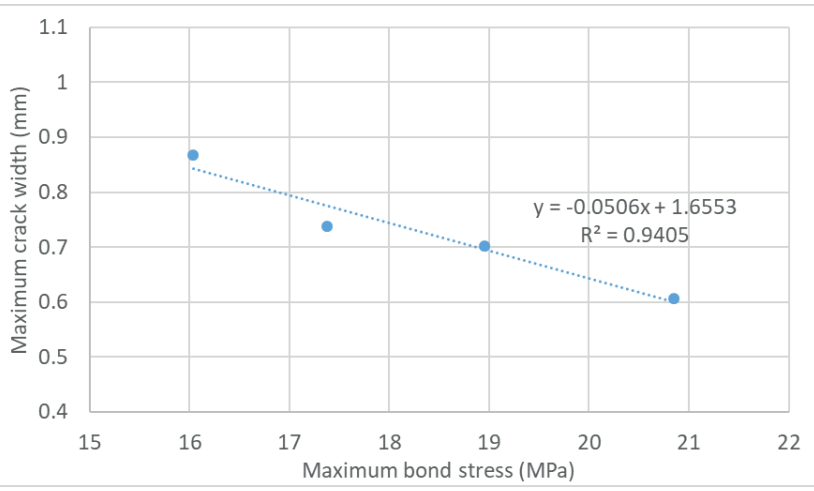

Fig. 20 The relationship between the bond stress and the maximum crack width at the failure width at the failure of the reinforced beam. The maximum crack width for all cases are $0.6064,0.7026,0.7384$, and $0.868 \mathrm{~mm}$, respectively. It was observed that the maximum crack width at the failure of the reinforced beam increased with decreasing bond stress; the same results were found in earlier studies by Law et al. [36] and Desnerck et al. [37].

The visible crack pattern for all cases at the middle region of the beam is shown in Fig. 21, where a filter was used to present only the cracks of $0.5 \mathrm{~mm}$ or larger. The figure shows a clear difference between the crack patterns. It can be seen from Fig. 21 that the number of cracks decreases when the maximum bond stress is increased, and that is logical where higher bond stress means better resistance to the appearance of cracks.

\subsection{Seven-wire strand}

\subsubsection{Case one: Using two strands (beam No. 2)}

In this case, the original bond stress-slip curve from the pull-out test was used (whole bond). The failure occurred with a force of $20.99 \mathrm{kN}$ and corresponding mid-span deflection equal to $56.46 \mathrm{~mm}$. When the bond stress values were multiplied by a factor equal to 2 , the failure occurred with a force of $18.51 \mathrm{kN}$ and corresponding midspan deflection equal to $50.97 \mathrm{~mm}$, as shown in Fig. 22. In these models, because of the high yield strength of the

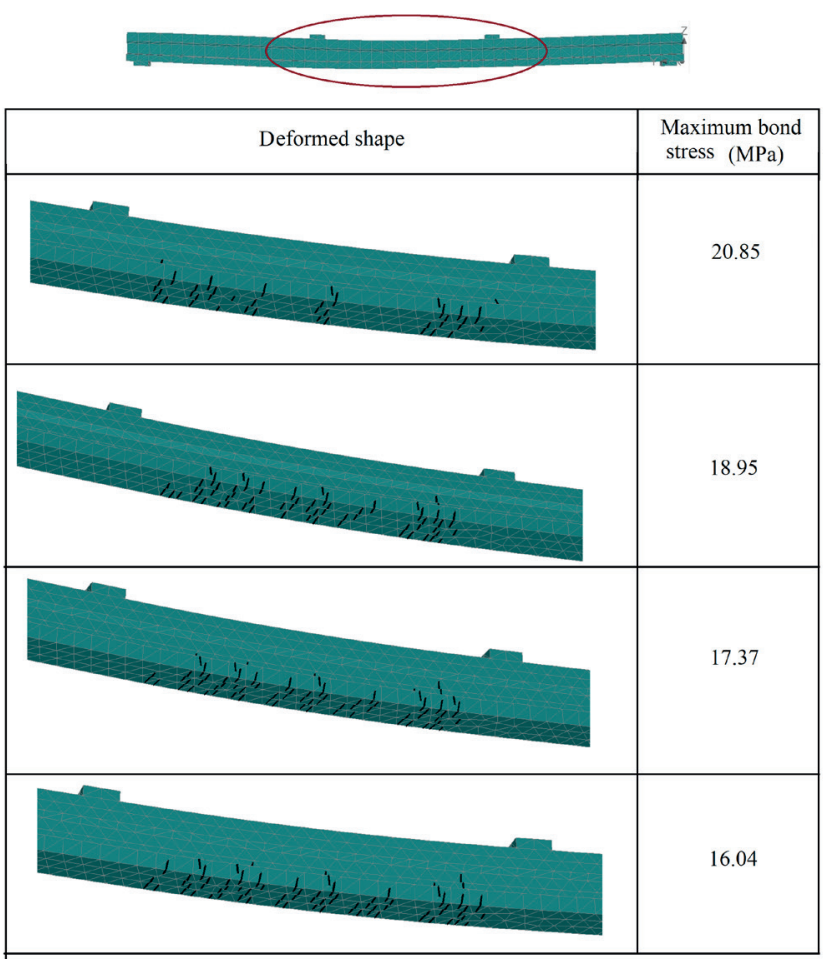

Fig. 21 The crack pattern of the reinforced concrete beam using different bond stress 


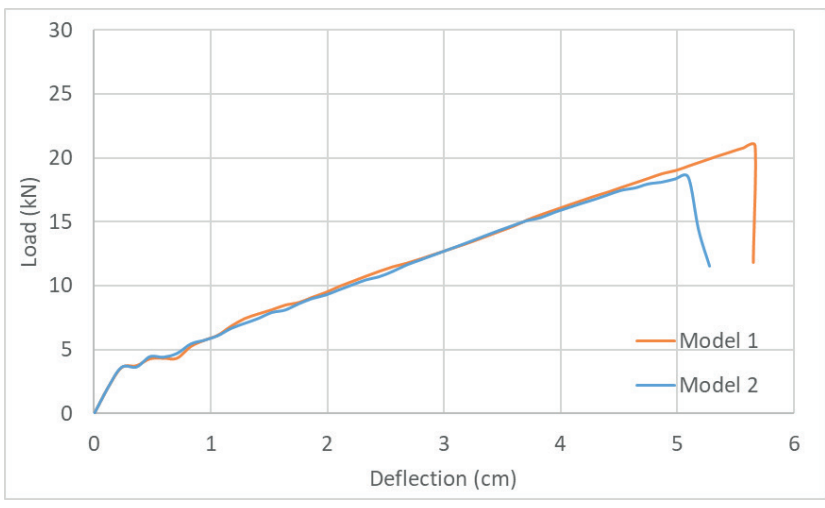

Fig. 22 The load-deflection curve for beam No. 2

strand $(1780 \mathrm{MPa})$, the concrete was crushed before reaching the strand yielded (concrete crushing failure). During the analysis until the failure, the maximum stress reached in the strand was approximately $921 \mathrm{MPa}$.

The strand did not reach the yield point with that stress, and the concrete crushed before reaching the yield point of the strand. Thus, the failure occurred in the concrete. The main reason for this behavior is that two strands were used as reinforcement of the beam, which is much more than the required reinforcement. It is not an appropriate choice from the perspective of the functionality and cost. Table 6 shows the influence of the bond stress on the deflection and maximum crack width, when the whole bond was used in the model (1), and double the whole bond was used in the model (2).

\subsubsection{Case two: Using one strand (beam No. 3)}

As in the previous case, the original bond stressslip curve from the pull-out test was used (whole bond). The failure occurred with a force of $21.5 \mathrm{kN}$ and corresponding mid-span deflection equal to $120 \mathrm{~mm}$. When the bond stress values were multiplied by a factor equal to 2 , the failure occurred with a force of about $21.5 \mathrm{kN}$ and the corresponding mid-span deflection equal to $117.32 \mathrm{~mm}$, as shown in Fig. 23. During the analysis the strand reached the maximum stress then the yielding phase started until

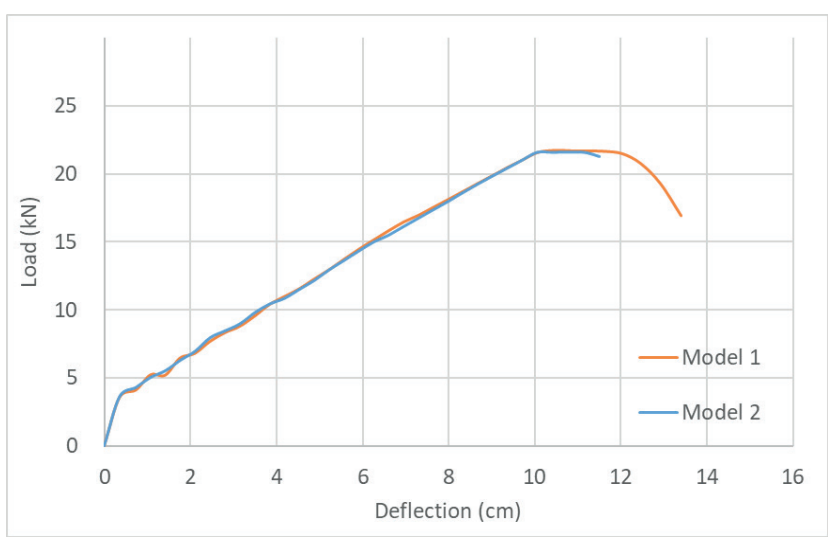

Fig. 23 The load-deflection curve for beam No. 3

the failure occurred. Table 7 shows the influence of the bond stress on the deflection and maximum crack width in which the whole bond was used in the model (1), and double the whole bond was used in the model (2).

\section{Conclusions}

Nowadays, numerical modeling is commonly used because experiments are sometimes not possible, or are very costly and time consuming. The bond stress-slip relationship is used to describe the bond behavior between reinforcing steel and concrete as the pull-out test assesses the strength of the bond. In this research, the pull-out test was simulated using a nonlinear finite element analysis in ATENA 3D, and the results were compared with existing experimental results to validate the model. Consequently, four-point static bending tests were simulated for a reinforced concrete beam without attribution on a real test, where the models used were the same as those used in the pull-out test. The types of reinforcing steel used in this research are ribbed steel bar and seven-wire strand, embedded in LWC with $85.3 \mathrm{MPa}$ strength. After examining the analyses, the following points are put forward:

- The results obtained by using ATENA 3D software was comparable to that obtained experimentally which express the real behavior.

Table 6 Influence of the bond stress on the deflection and maximum crack width

\begin{tabular}{|c|c|c|c|c|c|c|c|c|}
\hline \multirow{4}{*}{ Model } & \multicolumn{8}{|c|}{ Load $(\mathrm{kN})$} \\
\hline & \multicolumn{2}{|c|}{$25 \%$ of the failure load } & \multicolumn{2}{|c|}{$50 \%$ of the failure load } & \multicolumn{2}{|c|}{$75 \%$ of the failure load } & \multicolumn{2}{|c|}{ Failure load } \\
\hline & \multicolumn{8}{|c|}{ Deflection and crack width in $\mathrm{mm}$} \\
\hline & Deflection & Crack width & Deflection & Crack width & Deflection & Crack width & Deflection & Crack width \\
\hline $\begin{array}{l}\text { Model } 1 \\
\text { (Whole bond) }\end{array}$ & 8.28 & 0.077 & 23.31 & 0.17 & 38.31 & 0.248 & 56.64 & 0.379 \\
\hline $\begin{array}{l}\text { Model } 2 \\
\text { (Modified bond) }\end{array}$ & 7.12 & 0.066 & 19.82 & 0.144 & 33.69 & 0.209 & 50.90 & 0.338 \\
\hline
\end{tabular}


Table 7 Influence of the bond stress on the deflection and maximum

\begin{tabular}{|c|c|c|c|c|}
\hline \multirow{5}{*}{ Model } & \multicolumn{4}{|c|}{ crack width } \\
\hline & \multicolumn{4}{|c|}{ Load $(\mathrm{kN})$} \\
\hline & \multicolumn{2}{|c|}{$25 \%$ of the failure load } & \multicolumn{2}{|c|}{ Failure load } \\
\hline & \multicolumn{4}{|c|}{ Deflection and crack width in $\mathrm{mm}$} \\
\hline & Deflection & $\begin{array}{l}\text { Crack } \\
\text { width }\end{array}$ & Deflection & $\begin{array}{l}\text { Crack } \\
\text { width }\end{array}$ \\
\hline $\begin{array}{l}\text { Model } 1 \\
\text { (Whole bond) }\end{array}$ & 14.2 & 0.21 & 111.7 & 1.47 \\
\hline $\begin{array}{l}\text { Model } 2 \\
\text { (Modified bond) }\end{array}$ & 14.2 & 0.21 & 120.2 & 1.2 \\
\hline
\end{tabular}

- The bond stress in the case of the ribbed steel bar embedded in LWC is about $60 \%$ higher than that of the seven-wire strand embedded in LWC.

- It was possible to express the behavior of four-point static bending test by using ATENA 3D software without attribution on an experimental test but based on a validated model of the pull-out test for the same material characteristics. This saves effort and cost that needed to prepare and conduct the laboratory test.

- Losing the bond strength between reinforcement and concrete is clearly reflected in the cracking pattern of the reinforced beam.

\section{References}

[1] Abed, M., Nemes, R. "Mechanical Properties of Recycled Aggregate Self-Compacting High Strength Concrete Utilizing Waste Fly Ash, Cellular Concrete and Perlite Powders", Periodica Polytechnica Civil Engineering, 63(1), pp. 266-277, 2019.

https://doi.org/10.3311/PPci.13136

[2] Sarhan, M. M., Hadi, M. N. S., Teh, L. H. "Bond behaviour of steel plate reinforced concrete beams", Construction and Building Materials, 189, pp. 751-756, 2018.

https://doi.org/10.1016/j.conbuildmat.2018.09.024

[3] Engineers Association "Syrian Arab code for the design and implementation of reinforced concrete structures", Damascus, Syria, 2012.

[4] Hamad, B. S. "Bond Strength Improvement of Reinforcing Bars with Specially Designed Rib Geometries", ACI Structural Journal, 92(1), pp. 3-13, 1995.

http://doi.org/10.14359/1464

[5] Wassouf, M. "Bond and ductility of concrete reinforced with various steel bars surface and ductility conditions", $\mathrm{PhD}$ Thesis, University of Birmingham, 2015.

[6] Reinhardt, H. W., Balázs, G. L. "Steel-concrete interfaces: Experimental aspects", Studies in Applied Mechanics, 42, pp. 255-279, 1995.

https://doi.org/10.1016/S0922-5382(06)80014-0

[7] Tepfers, R., Achillides, Z. "Bond of reinforcement in concrete", Bulletin No. 10, International Federation for Structural Concrete, Lausanne, Switzerland, 2000.

https://doi.org/10.35789/fib.BULL.0010
- Using a high amount of reinforcement (two strands) is not an economic choice, and concrete failure occurred before the yield point of the strand was reached.

- Using one strand as beam reinforcement, the failure occurred as a result of increasing the strand yielding point.

Both the maximum deflection of the reinforced concrete beam and the maximum crack width before and at the failure of the beam are influenced by the bond stress between the concrete and the reinforcement (ribbed steel bar and seven-wire strand). The maximum crack width and the maximum mid-span deflection of the reinforced concrete beam increase when the bond stress between the concrete and the reinforcement is decreased. The relationship is negative linear between the bond stress and both the maximum deflection and crack width of the reinforced concrete beam.

\section{Acknowledgement}

The authors wish to thank TKP2020 research and also the assistant professor in the Department of Structural Engineering at Budapest University of Technology and Economics, Dr. Zsolt Huszár, for his endless support.

[8] Daczko, J. "Self-Consolidating Concrete: Applying what we know", CRC Press, London, UK, 2012. https://doi.org/10.1201/b11721

[9] Clarke, J. L. "Structural Lightweight Aggregate Concrete", CRC Press, London, UK, 1993. https://doi.org/10.1201/9781482269307

[10] Holand, I. "Lightweight aggregate concrete - Codes and standards", Bulletin No. 04, International Federation for Structural Concrete, Lausanne, Switzerland, 1999. https://doi.org/10.35789/fib.bull.0004

[11] Chandra, S., Berntsson, L. "Lightweight Aggregate Concrete", William Andrew, Norwich, NY, USA, 2002.

[12] Chen, H.-J., Huang, C.-H., Kao, Z.-Y. "Experimental investigation on steel-concrete bond in lightweight and normal weight concrete", Structural Engineering and Mechanics, 17(2), pp. 141-152, 2004. https://doi.org/10.12989/sem.2004.17.2.141

[13] Carmo, R. N. F., Costa, H., Bento, G. "Experimental investigation of bond stress and deformations in LWAC ties reinforced with GFRP bars", Strain, 50(4), pp. 318-333, 2014. https://doi.org/10.1111/str.12094

[14] Wu, X., Wu, Z., Zheng, J., Zhang, X. "Bond behaviour of deformed bars in self-compacting lightweight concrete subjected to lateral pressure", Magazine of Concrete Research, 65(23), pp. 1396-1410, 2013. https://doi.org/10.1680/macr.13.00123

[15] Orangun, C. O. "The bond resistance between steel and lightweightaggregate (Lytag) concrete", Building Science, 2(1), pp. 21-28, 1967. https://doi.org/10.1016/0007-3628(67)90004-7 
[16] Teo, D. C. L., Mannan, M. A., Kurian, V. J., Ganapathy, C. "Lightweight concrete made from oil palm shell (OPS): Structural bond and durability properties", Building and Environment, 42(7), pp. 2614-2621, 2007. https://doi.org/10.1016/j.buildenv.2006.06.013

[17] Gunasekaran, K., Annadurai, R., Kumar, P. S. "Long term study on compressive and bond strength of coconut shell aggregate concrete", Construction and Building Materials, 28(1), pp. 208-215, 2012. https://doi.org/10.1016/j.conbuildmat.2011.08.072

[18] Pul, S. "Loss of concrete-steel bond strength under monotonic and cyclic loading of lightweight and ordinary concretes", Iranian Journal of Science \& Technology, Transaction B: Engineering, 34(B4), pp. 397-406, 2005. https://doi.org/10.22099/IJSTC.2012.691

[19] Gulyás, G., Kovács, T., Nemes, R. "Bond between strands and high-strength normal-weight and lightweight aggregate concretes", Építés - Építészettudomány, 42(3-4), pp. 261-280, 2014. (in Hungarian) https://doi.org/10.1556/eptud.42.2014.3-4.8

[20] Eligehausen, R., Bigaj, A. "Structural Concrete Textbook on behavior, design and performance, Second edition Volume 1: Design of concrete structures conceptual design, materials", Bulletin No. 51, International Federation for Structural Concrete, Lausanne, Switzerland, 2009. https://doi.org/10.35789/fib.bull.0051

[21] Comite Euro International du Beton "CEB-FIP Model Code 1990", Thomas Telford, London, UK, 1993. https://doi.org/10.1680/ceb-fipmc1990.35430

[22] Special Activity Group 5, New Model Code "fib Model Code for Concrete Structures 2010", Ernst \& Sohn Wiley, Berlin, Germany, 2013.

https://doi.org/10.1002/9783433604090

[23] Yoo, D.-Y., Shin, H.-O. "Bond performance of steel rebar embedded in 80-180 MPa ultra-high-strength concrete", Cement and Concrete Composites, 93, pp. 206-217, 2018. https://doi.org/10.1016/j.cemconcomp.2018.07.017

[24] Floyd, R. W. "Investigating the bond of prestressing strands in lightweight self-consolidating concrete", PhD Dissertation, University of Arkansas, 2012.

[25] Li, F., Yuan, Y. "Effects of corrosion on bond behavior between steel strand and concrete", Construction and Building Materials, 38, pp. 413-422, 2013.

https://doi.org/10.1016/j.conbuildmat.2012.08.008

[26] Jiang, X. "Bond Performance of High-Capacity Strands in High Strength Concrete", PhD Dissertation, University of Tennessee, 2013.
[27] Chao, S.-H., Naaman, A. E., Parra-Montesinos, G. J. "Bond Behavior of Strand Embedded in Fiber Reinforced Cementitious Composites", PCI Journal, 51(6), pp. 56-71, 2006. https://doi.org/10.15554/pcij.11012006.56.71

[28] Yu, H., Jeong, D. "Finite Element Bond Modeling for Indented Wires in Pretensioned Concrete Crossties", presented at Proceedings of the 2016 Joint Rail Conference. 2016 Joint Rail Conference, Columbia, SC, USA, April, 12-15, 2016, Paper No: JRC2016-5782. https://doi.org/10.1115/JRC2016-5782

[29] Tavares, A. J., Barbosa, M. P., Bittencourt, T. N., Lorrain, M. "Aderência aço-concreto: simulação numéricadosensaios de arranchamento pull-out e APULOT usando o programa ATENA" (Bond steel-concrete: simulation analysis of the pull-out tests and APULOT using the program ATENA), Revista IBRACON de Estruturas e Materiais, 7(1), pp. 138-157, 2014. (in Portuguese) https://doi.org/10.1590/S1983-41952014000100007

[30] Červenka, V., Jendele, L., Cervenka, J. "Atena Program Documentation, Part 1, Theory", Cervenka Consulting, Prague, Czech Republic, 2007.

[31] Windisch, A. "A modified pull-out test and new evaluation methods for a more real local bond-slip relationship", Materials and Structures, 18(3), pp. 181-184, 1985. https://doi.org/10.1007/BF02472967

[32] RILEM TC "RC 6 Bond test for reinforcement steel. 2. Pull-out test, 1983", In: RILEM Recommendations for the Testing and Use of Constructions Materials E \& FN SPON, New York, NY, USA, 1994. pp. 218-220. https://doi.org/10.1617/2351580117.081

[33] Červenka, J., Procházková, Z., Sajdlová, T. "ATENA Program Documentation, Part 4-2, Tutorial for Program ATENA 3D", Cervenka Consulting, Prague, Czech Republic, 2017.

[34] Bolmsvik, R., Lundgren, K. "Modelling of bond between three-wire strands and concrete", Magazine of Concrete Research, 58(3), pp. 123-133, 2006.

https://doi.org/10.1680/macr.2006.58.3.123

[35] Mousa, M. I. "Effect of bond loss of tension reinforcement on the flexural behaviour of reinforced concrete beams", HBRC Journal, 12(3), pp. 235-241, 2016. https://doi.org/10.1016/j.hbrcj.2015.01.003

[36] Law, D. W., Tang, D., Molyneaux, T. K. C., Gravina, R. "Impact of crack width on bond: confined and unconfined rebar", Materials and Structures, 44(7), pp. 1287-1296, 2010. https://doi.org/10.1617/s11527-010-9700-y

[37] Desnerck, P., Lees, J. M., Morley, C. T. "Bond behaviour of reinforcing bars in cracked concrete", Construction and Building Materials, 94, pp. 126-136, 2015. https://doi.org/10.1016/j.conbuildmat.2015.06.043 